\title{
Journey towards World Class Stations: An Assessment of Platform Amenities at Allahabad Junction
}

\author{
Geetika, Piyali Ghosh, Mohit Kumar Ojha, and Sumit Kumar \\ Motilal Nehru National Institute of Technology
}

\begin{abstract}
Passengers spend considerable time on railway platforms using amenities thereon; thus, making their stay pleasurable would result in passenger satisfaction for a rail journey. The Ministry of Railways in India has initiated plans for developing stations of worldclass standards by delivering state-of-the-art facilities and quality services at platforms. This paper is an attempt to assess levels of importance and satisfaction perceived by passengers with respect to amenities on platforms of Allahabad Junction in the State of Uttar Pradesh, India. A total of 32 platform amenities examined through a sample of 1,248 passengers were grouped under 7 factors using Exploratory Factor Analysis. A service quality performance matrix was prepared thereafter to identify amenities needing improvement, and a Customer Satisfaction Index was calculated to determine a priority order for improvement of these amenities. Security and cleanliness were revealed to be the aspects that need improvement. Findings of this study are expected to be useful for policymakers working on the concept of world-class stations.
\end{abstract}

Keywords: Passenger satisfaction, Indian Railways, Allahabad Junction, railway platform, world class stations, service quality performance matrix

\section{Introduction}

Movement of people and materials between places is a necessary corollary of modern life. People have to travel from one place to the other to satisfy their personal, professional, psychological, social, religious, recreational, and other needs. Considering these aspects, public transport is regarded as a long-term solution for mobility (Hanumappa et al. 2015). Rail is a preferred mode of transportation in India for various reasons, such as its wide network, accessibility, affordability, and ease of travel. However, in spite of being considered as a barometer of the country's economic growth, Indian Railways has lost market share in its freight and passenger segment due to lack of customer responsiveness and poor public perception (Railway Board 2009). Especially 
when it comes to quality of service, concerns arise about rail, be it in the context of quality of transit or rail coaches or railway platforms. Problems such as overcrowding, unauthorized vending, lack of amenities, waiting lounges, access control, and passenger guidance systems (Sharma 2009) result in an unpleasant stay for passengers and adversely affect their satisfaction with their rail journey.

Customer satisfaction is a state of mind (Juran 1998), a cumulative construct that is a function of service expectations and performance perceptions in a given period of time (Samen et al. 2012). In the context of transportation, passenger satisfaction is created by comparing pre-travel expectations and post-travel experiences (Gronroos 1988, cited from Guirao et al. 2015; Lei and Chen 2010). The quality of stations has a positive impact on the overall perception of passengers about a rail journey (Givoni and Rietveld 2007), and provision of adequate and quality services help in making a passenger's stay pleasurable (Dash, Dash, and Pradhan 2012). Considering the passenger base of Indian Railways and the considerable portion of travel time spent by passengers on platforms, it is important that amenities available at platforms match passenger expectations to ensure their satisfaction and make their experience pleasurable.

This study draws motivation from a perceived need to conduct exploratory research on railway stations to assess the level of passenger satisfaction with amenities available at platforms and ascertain which amenities need improvement. For this purpose, a study of Allahabad Division was undertaken. Allahabad is the headquarters of the North Central Railway Zone of Indian Railways. It has 1 junction station and 8 satellite stations, and the junction has 10 platforms to cater to 2 of the busiest routes, New Delhi-Howrah and Mumbai-Howrah.

This study applied the concept of a service quality performance matrix proposed by Hung, Huang, and Chen (2003) on Indian Railways to measure the satisfaction level of passengers with amenities at platforms in the first step, and a customer satisfaction index (CSI) (Yang 2003; Giannoccaro et al., 2008) was constructed in the next step to prioritize amenities that need improvement. This methodology marks a departure from earlier studies on Indian Railways, especially in the context of specific amenities available at railway platforms; thus, it contributes to the body of literature on public transportation, especially railways.

The next section discusses the relevance of the study, followed by a summary of extant literature on passenger satisfaction from amenities at railway platforms. The research plan adopted, an analysis of data, and conclusions and recommendations are presented next. The last section summarizes the limitations of the study and highlights a scope for further research.

\section{Relevance of the Study}

There are two main components of rail travel-the passenger stay on a platform for boarding or alighting from a train and the stay in trains. A railway platform is an important component of factors such as reliability, service, and information concerns of railways; this is because information and facilities provided at platforms constitute part of the service before and after a trip and can cause delay and reliability issues 
(Pettersson 2011). Therefore, improving amenities available at platforms plays a vital role in enhancing the performance of the service provider in meeting passenger expectations from an entire trip. Hence, the focus in this study was on determining passenger satisfaction levels with various amenities at platforms and their relative perceived importance levels to get an insight into the gap between the importance and satisfaction levels of individual amenities and to suggest areas for improvement in order of priority.

The relevance of this research and the choice of Allahabad Junction to assess platform amenities can be explained from two perspectives, the first of which is the concept of world-class stations. In 2006, Indian Railways identified 16 metro and mini stations to be developed into world-class stations with modern facilities and a high-quality appearance. Pursuant to the Vision-2020 document promulgated by the Ministry of Railways, Government of India, for modernization of rail services, the list was extended in 2012 and includes Allahabad Junction. Commitment to the purpose of world-class stations is evidenced by the fact that the Ministry allocated Rs. 10,000 billion with the objective of redeveloping stations and logistic parks, which is around $12 \%$ of the proposed investment plan for 2015-19 (www.indianrailways.gov.in).

Second, by including aspects of cleanliness and hygiene in measuring satisfaction and importance, the present study finds relevance in the wake of the flagship program of the Government of India to embark on a nationwide cleanliness drive, Swachh Bharat Abhiyan, which has motivated Indian Railways to launch the Swachh Rail-Swachh Bharat mission towards providing and maintaining a clean and hygienic environment not only in trains but also at railway stations.

The outcome of this research might provide a framework to policymakers and planners in redeveloping railway stations that meet world-class standards.

\section{Review of the Literature}

Several studies on railways have attempted to measure passenger satisfaction level with amenities available at platforms and in trains. For example, Le-Klähn, Hall, and Gerike (2015) ascertained passenger satisfaction with public transportation including suburban trains, underground trains, trams, and local buses in Munich, Germany. Factor analysis yielded four service dimensions - traveling comfort, service quality, accessibility, and additional features contributing to passenger satisfaction. Evaluating railway services in Indonesia, Pratminingsih, Rudatin, and Suhardi (2014) considered the constructs of perceived quality, perceived value, trust, satisfaction, and passenger loyalty and concluded that all have significant positive inter-relationships and lead to overall passenger satisfaction. Esmaeili, Manesh, and Golshan (2013) established a significant relationship of service quality with customer satisfaction and customer loyalty and between customer satisfaction and customer loyalty in their study of stations in Tehran. A report by the Gallup Organization (2011) based on a study spanning several European countries showed that customers are most satisfied with the aspects of ease of buying tickets, provision of information about train schedules/platform, and personal security in stations. Facilities for car parking, the quality of facilities and services, and cleanliness/ good maintenance of station facilities were the major dissatisfiers. 
Evaluating rail services at Coimbatore Junction in India, Gandhimathi and Saravanan (2013) suggested seven factors that are important for passenger satisfaction. According to passenger ratings, comfort, tangibles, and assurance were the top three factors, followed by empathy, frequency, speed, and reliability. In an empirical investigation of Indian Railways by Sheeba and Kumuthadevi (2013), 16 variables for measuring passenger satisfaction were grouped under 7 factors - basic facilities, hygiene, safety and security, catering, health care services, punctuality, and behavior towards passengers.

Gupta and Dutta (2012) took the case of Howrah Junction and prioritized reduction in waiting time, upgrading of security systems, upgrading of travel-associated facilities, improvement in passenger amenities, improvement in accessibility, and enhancement of information availability as the physical and functional requirements of passengers. Geetika and Nandan (2010) identified 16 parameters for measuring the passenger satisfaction level with services at platforms in a study of Allahabad Junction that were further grouped into 5 factors-refreshment, behavior, information system efficiency, basic facility, and security. Of these, quality of refreshment and behavior of staff were found to be the most significant predictors. In another study on Indian Railways, Agarwal (2008) considered 47 attributes to assess the effect of consumer perceptions about different service aspects of public transportation services on their satisfaction level; customer-oriented basic platform services was the most important factor, followed by employee behavior (Gupta and Dutta 2012).

\section{Objectives of the Study}

This study aimed to ascertain the importance-satisfaction paradigm of amenities available at railway platforms. The first objective, therefore, was to measure passenger satisfaction from such amenities considering platforms at Allahabad Junction. The second objective was to determine the passenger perception about the importance levels of the respective amenities to highlight the gap between levels of importance and satisfaction. For this purpose, a service quality performance matrix was developed to analyze importance-satisfaction gaps. To prioritize amenities for improvement, a customer satisfaction index was calculated. The outcome of this paper is a set of various categories of platform amenities in the importance-satisfaction relationship.

\section{Research Plan}

This study was empirical in nature based on primary data, and a questionnaire-based survey method was used for data collection. The population of passengers being of a floating nature, a judgmental sampling technique was used per the number of footfalls on platforms. To address possible limitations of this technique, the survey spanned a period of 7 days at all 10 platforms of Allahabad Junction during different time periods; this helped to contact varied types of passengers coming from or going to various parts of the country.

An exhaustive list of 46 amenities was prepared as an outcome of a preliminary investigation of platforms at Allahabad Junction and was included in a structured questionnaire used for collecting data from passengers on these amenities on the basis of two aspects: their importance as perceived by respondent passengers and satisfaction 
level with such amenities. To measure responses, a five-point Likert-type scale was used. In total, 1,250 questionnaires were completed using a personal interaction method. At the end of the survey, 1,248 questionnaires were found to be complete and usable, thereby registering a response rate of $99.84 \%$.

Extant literature provides evidence of a large number of factors that are significant predictors of passenger satisfaction with a rail journey and/or amenities at platforms. Satisfaction is a comprehensive and broad concept that includes service quality, price, and personal and situational factors (Zeithaml and Bitner 1996). It is also related to affective judgments (Choi et al. 2004; Chen 2008). Exploratory Factor Analysis (EFA) was conducted on all 46 amenities to determine those amenities that are important from the passenger perspective. To measure satisfaction level, only those amenities that were identified by EFA were considered. A service quality performance matrix was constructed in the next step to identify amenities on which the Ministry of Railways needs to define its improvement action plans for delivering maximum satisfaction to passengers.

The service quality performance matrix (Figure 1 ) is a $3 \times 3$ matrix with 9 performance zones. The original matrix was developed by Lambert and Sharma (1990) and redeveloped by Hung, Huang, and Chen (2003). Importance and satisfaction indices were calculated using the following formula given by Chen et al. (2007):

$$
\begin{aligned}
& \text { Index of Importance }=\frac{\mu_{I}-\min }{R} \\
& \text { Index of Satisfaction }=\frac{\mu_{S}-\min }{R}
\end{aligned}
$$

where $\mu_{\mathrm{I}}$ and $\mu_{\mathrm{S}}$, represent means of importance and satisfaction levels, respectively; min indicates the minimum of the scale used in this study; and $R$ is the full range of the scale, i.e., highest-lowest.

\section{FIGURE 1.}

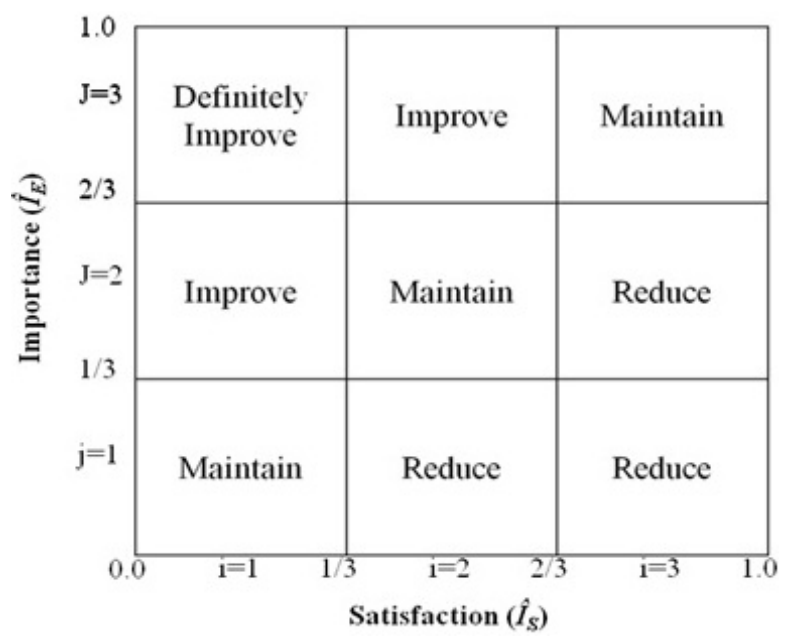

Source: Hung, Huang, and Chen 2003 
The indices used are decimal numbers between 0 and 1 , and the matrix is divided into three equal intervals using four scales- $-0.0,1 / 3,2 / 3$, and 1.0. The three equal intervals of $0.0-1 / 3,1 / 3-2 / 3$, and $2 / 3-1.0$ represent low satisfaction/importance, moderate satisfaction/importance, and high satisfaction/importance zones, respectively. The nine zones formed in the matrix are divided into four regions-Definitely Improve (Low Satisfaction-High Importance Zone or LS-HI); Improve, with two zones (Low Satisfaction-Moderate Importance or LS-MI and Moderate Satisfaction-High Importance or MS-HI); Maintain, with three zones (Low Satisfaction-Low Importance or LS-LI, Moderate Satisfaction-Moderate Importance or MS-MI, and High Satisfaction-High Importance or HS-HI); and Reduce, with three zones (Moderate Satisfaction-Low Importance or MS-LI, High Satisfaction-Low Importance or HS-LI, and High Satisfaction-Moderate Importance or HS-MI).

However, if some items lie on the borderline between different zones, it becomes difficult to give recommendations for such items. Further, identifying items only that need improvement is not enough; the priority order of items to be improved must be determined (Chen et al. 2007). Hence, to deal with the difficulty of deciding on a particular zone for items falling on a borderline, it was assumed that items were in the Improvement zone if they were on the border of the Improvement and Maintain zones and in the Maintain zone if they were on the border of Maintain and Reduce.

Second, since the service quality performance matrix does not define any priority order of amenities for improvement, a Customer Satisfaction Index (CSI) was computed. If the service provider organization has abundant resources at its disposal, it can plan its improvement actions for all items that need improvement. But when resources are scarce, which usually is the case, it has to select items for improvement, because it is then neither feasible nor advisable for the organization to invest in each and every item. Hence, the service provider has to determine priority, i.e., which items need to be improved first and which can be improved later. Following this rule, it would first take up items falling in the Improvement zone and, in next step, would assign priority to such items for their improvement. To determine the priority for improvement of each individual item falling in the Improvement zone in the service quality performance matrix, CSI was calculated using the following formula:

$$
\mathrm{CSI}_{\mathrm{i}}=\mathrm{I}_{\mathrm{i}} \times \mathrm{S}_{\mathrm{i}}
$$

where, $\mathrm{CSI}_{\mathrm{i}} \mathrm{i}$ is the Customer Satisfaction Index for $\mathrm{ith}$ item, $\mathrm{I}_{\mathrm{i}}$ is the mean of the importance score given by the respondent for ith item, and $\mathrm{S}_{i}$ is the mean of the satisfaction score given by the respondent for ith item. The lower the CSI, the higher the priority for improvement of a particular item, because a low CSI indicates that the gap between the importance score and the satisfaction score is high for that item.

\section{Analysis of Data}

\section{Results of Exploratory Factor Analysis}

A KMO value of 0.568 being more than 0.5 (Field 2009) verifies sample adequacy for factor analysis. Bartlett's test of sphericity provides an acceptable value of 12,180 at a $5 \%$ level of significance. While conducting EFA, principal component analysis with 
Varimax rotation was used, and after applying a cut-off of 0.51 on factor loadings, the rotated component matrix reduced the selected 46 amenities to 32 items grouped under 7 factors, accounting for $65.215 \%$ of the total variance (see Table 1 ) and named as passenger amenities, cleanliness, safety $\&$ security, access to station premises, waiting time, announcement system, and other amenities.

TABLE 1.

Total Variance

Explained

\begin{tabular}{|c|c|c|c|c|c|c|c|c|c|}
\hline \multirow[t]{2}{*}{ Component } & \multicolumn{3}{|c|}{ Initial Eigenvalues } & \multicolumn{3}{|c|}{$\begin{array}{l}\text { Extraction Sums of Squared } \\
\text { Loadings }\end{array}$} & \multicolumn{3}{|c|}{$\begin{array}{c}\text { Rotation Sums of Squared } \\
\text { Loadings }\end{array}$} \\
\hline & Total & $\begin{array}{c}\% \text { of } \\
\text { Variance }\end{array}$ & $\begin{array}{c}\text { Cumulative } \\
\%\end{array}$ & Total & $\begin{array}{c}\% \text { of } \\
\text { Variance }\end{array}$ & $\begin{array}{c}\text { Cumulative } \\
\%\end{array}$ & Total & $\begin{array}{c}\% \text { of } \\
\text { Variance }\end{array}$ & $\begin{array}{c}\text { Cumulative } \\
\%\end{array}$ \\
\hline 1 & 14.219 & 31.598 & 31.598 & 14.219 & 31.598 & 31.598 & 5.796 & 12.880 & 12.880 \\
\hline 2 & 4.069 & 9.042 & 40.640 & 4.069 & 9.042 & 40.640 & 5.053 & 11.229 & 24.109 \\
\hline 3 & 3.079 & 6.841 & 47.481 & 3.079 & 6.841 & 47.481 & 4.997 & 11.104 & 35.213 \\
\hline 4 & 2.407 & 5.350 & 52.831 & 2.407 & 5.350 & 52.831 & 3.781 & 8.403 & 43.616 \\
\hline 5 & 2.194 & 4.876 & 57.707 & 2.194 & 4.876 & 57.707 & 3.715 & 8.255 & 51.871 \\
\hline 6 & 1.774 & 3.943 & 61.650 & 1.774 & 3.943 & 61.650 & 3.500 & 7.777 & 59.648 \\
\hline 7 & 1.604 & 3.565 & 65.215 & 1.604 & 3.565 & 65.215 & 2.505 & 5.567 & 65.215 \\
\hline
\end{tabular}

Extraction Method: Principal Component Analysis

Table 2 shows the factors with their respective factor loadings.

TABLE 2.

Factors and Factor Loadings

\begin{tabular}{|c|c|c|c|c|}
\hline Factors & $\begin{array}{c}\text { Cronbach } \\
\text { Alpha }\end{array}$ & Dimensions & $\begin{array}{l}\text { Factor } \\
\text { Loadings }\end{array}$ & $\begin{array}{c}\text { Mean } \\
\text { (Importance } \\
\text { Level) }\end{array}$ \\
\hline \multirow{8}{*}{$\begin{array}{c}1 \\
\text { Passenger } \\
\text { Amenities }\end{array}$} & \multirow{8}{*}{0.894} & Refreshment quality & 0.778 & 4.47 \\
\hline & & Refreshment affordability & 0.692 & 4.39 \\
\hline & & Fans at platforms & 0.633 & 4.27 \\
\hline & & Lighting at platforms & 0.621 & 4.48 \\
\hline & & Drinking water & 0.607 & 4.52 \\
\hline & & Waiting room & 0.58 & 4.55 \\
\hline & & Washroom facility & 0.541 & 4.4 \\
\hline & & Platform display & 0.533 & 4.35 \\
\hline \multirow{7}{*}{$\begin{array}{c}2 \\
\text { Cleanliness }\end{array}$} & \multirow{7}{*}{0.892} & Cleanliness in washrooms & 0.887 & 4.58 \\
\hline & & Cleanliness near seating chairs & 0.842 & 4.58 \\
\hline & & Cleanliness near waiting room & 0.757 & 4.53 \\
\hline & & Cleanliness at platforms & 0.664 & 4.56 \\
\hline & & Cleanliness near refreshment stalls & 0.662 & 4.55 \\
\hline & & Cleanliness near water points & 0.647 & 4.68 \\
\hline & & Cleanliness on tracks & 0.598 & 4.29 \\
\hline \multirow{3}{*}{$\begin{array}{c}3 \\
\text { Safety \& } \\
\text { Security }\end{array}$} & \multirow{3}{*}{0.897} & Security of self & 0.756 & 4.42 \\
\hline & & Police assistance booths (GRP) & 0.696 & 4.47 \\
\hline & & Security of luggage & 0.694 & 4.35 \\
\hline
\end{tabular}




\begin{tabular}{|c|c|c|c|c|}
\hline Factors & $\begin{array}{c}\text { Cronbach } \\
\text { Alpha }\end{array}$ & Dimensions & $\begin{array}{l}\text { Factor } \\
\text { Loadings }\end{array}$ & $\begin{array}{c}\text { Mean } \\
\text { (Importance } \\
\text { Level) }\end{array}$ \\
\hline \multirow{6}{*}{$\begin{array}{c}4 \\
\text { Access to } \\
\text { Station } \\
\text { Premises }\end{array}$} & \multirow{6}{*}{0.791} & Two-wheeler parking space & 0.766 & 3.89 \\
\hline & & Availability of foot-over bridges & 0.678 & 4.11 \\
\hline & & Four-wheeler parking space & 0.672 & 3.76 \\
\hline & & Accessibility of station on foot & 0.669 & 3.92 \\
\hline & & $\begin{array}{l}\text { Accessibility of other modes of } \\
\text { transportation }\end{array}$ & 0.643 & 4.08 \\
\hline & & Availability of escalators & 0.533 & 4.03 \\
\hline \multirow{2}{*}{$\begin{array}{c}5 \\
\text { Waiting Time }\end{array}$} & \multirow{2}{*}{0.653} & Waiting time at enquiry counter & 0.546 & 4.19 \\
\hline & & Waiting time for travel related information & 0.529 & 3.95 \\
\hline \multirow{2}{*}{$\begin{array}{c}6 \\
\text { Announcement } \\
\text { System }\end{array}$} & \multirow{2}{*}{0.842} & Clarity of announcement & 0.796 & 4.45 \\
\hline & & Accuracy of announcement & 0.777 & 4.45 \\
\hline \multirow{4}{*}{$\begin{array}{c}7 \\
\text { Other } \\
\text { Amenities }\end{array}$} & \multirow{4}{*}{0.658} & Internet facilities & 0.732 & 3.77 \\
\hline & & ATMs & 0.664 & 4.31 \\
\hline & & Mobile charging points & 0.647 & 4.16 \\
\hline & & Cloak room & 0.609 & 3.79 \\
\hline
\end{tabular}

- Factor 1 (Passenger Amenities) ( $\alpha=0.894)$ - Provision of amenities such as waiting room, drinking water, and washrooms is a basic requirement of passengers at platforms, and their satisfaction with rail travel was found to depend on the availability of these amenities. This is in consonance with the findings of previous studies (e.g., Rahman and Rahman 2009; Geetika and Nandan 2010; Sheeba and Kumuthadevi 2013).

- Factor 2 (Cleanliness) $(\alpha=0.892)$ - Cleanliness as a service dimension has been a subject and outcome of several studies, especially in the context of railways. For example, cleanliness was one of the service quality attributes of passenger rail systems in the U.S. identified by Drea and Hanna (2000).

- Factor 3 (Safety \& Security) $(\alpha=0.897)$ - Social safety is an important element considered necessary for passengers to feel comfortable at railway platforms while waiting (Cavana, Corbett, and Lo 2007; Rahman and Rahman 2009; Van Hagen 2011, cited from Vos 2013). People may even choose not to travel by public transportation if they do not feel safe in such an environment (Atkins 1990; Van't Hof 2008, cited from Vos 2013).

- Factor 4 (Access to Station Premises) $(\alpha=0.791)$ - Passengers expect appropriate provisions for accessing railway platforms. Our findings correspond to the study of Cavana, Corbett, and Lo (2007), in which connectivity was established as an important factor affecting passenger perception of service quality.

- Factor 5 (Waiting Time) $(\alpha=0.653)$ - Passengers expect timely provision of services and prefer not to wait too long for their delivery. Factor analysis reveals 
that the extent of waiting contributes towards the satisfaction level of travelers. A similar finding was reported by Sheeba and Kumuthadevi (2013).

- Factor 6 (Announcement System) $(\alpha=0.842)$ - This factor has two dimensions, clarity and accuracy. Appropriate and timely information is what passengers expect from railways, and information emerged as an important predictor of passenger satisfaction in earlier studies (e.g., Cavana, Corbett, and Lo 2007; Rahman and Rahman 2009; Geetika and Nandan 2010; Swami and Parida 2015).

- Factor 7 (Other Amenities) $(\alpha=0.658)$ - Various amenities under this factor include cloak room, ATMs, mobile charging points, and internet facilities on platforms.

\section{Service Quality Performance Matrix}

To construct the service quality performance matrix, first, the importance and satisfaction indices were calculated for the 32 amenities that emerged from the EFA, using equations 1 and 2 (Table 3). Coordinates for each amenity then were mapped in the performance matrix (Figure 2).

TABLE 3.

\begin{tabular}{|c|c|c|c|c|c|}
\hline & Amenities & $\begin{array}{c}\text { Mean } \\
\text { (Importance } \\
\text { Level) }\end{array}$ & $\begin{array}{c}\text { Mean } \\
\text { (Satisfaction } \\
\text { Level) }\end{array}$ & $\begin{array}{l}\text { Importance } \\
\text { Index }\left(\hat{I}_{E}\right)\end{array}$ & $\begin{array}{l}\text { Satisfaction } \\
\text { Index }\left(\hat{I}_{S}\right)\end{array}$ \\
\hline 1 & Waiting room & 4.55 & 3.31 & 0.887500 & 0.5775 \\
\hline 2 & Lighting at platforms & 4.48 & 3.63 & 0.870000 & 0.6575 \\
\hline 3 & Fans in platforms & 4.27 & 2.94 & 0.817500 & 0.4850 \\
\hline 4 & Platform display & 4.35 & 3.29 & 0.837500 & 0.5725 \\
\hline 5 & Drinking water & 4.52 & 3.34 & 0.880000 & 0.5850 \\
\hline 6 & Refreshment quality & 4.47 & 3.00 & 0.867500 & 0.5000 \\
\hline 7 & Refreshment affordability & 4.39 & 3.27 & 0.847500 & 0.5675 \\
\hline 8 & Washroom facility & 4.40 & 3.13 & 0.850000 & 0.5325 \\
\hline 9 & Cleanliness at platforms & 4.56 & 3.00 & 0.890000 & 0.5000 \\
\hline 10 & Cleanliness on tracks & 4.29 & 2.53 & 0.822500 & 0.3825 \\
\hline 11 & $\begin{array}{l}\text { Cleanliness near waiting } \\
\text { room }\end{array}$ & 4.53 & 3.11 & 0.882500 & 0.5275 \\
\hline 12 & $\begin{array}{l}\text { Cleanliness near seating } \\
\text { chairs }\end{array}$ & 4.58 & 3.19 & 0.895000 & 0.5475 \\
\hline 13 & Cleanliness in washrooms & 4.58 & 2.77 & 0.895000 & 0.4425 \\
\hline 14 & $\begin{array}{l}\text { Cleanliness near refreshment } \\
\text { stalls }\end{array}$ & 4.55 & 3.05 & 0.887500 & 0.5125 \\
\hline 15 & Cleanliness near water points & 4.68 & 3.06 & 0.920000 & 0.5150 \\
\hline 16 & Security of self & 4.42 & 2.81 & 0.855000 & 0.4525 \\
\hline 17 & Security of luggage & 4.35 & 2.6 & 0.837500 & 0.4000 \\
\hline 18 & $\begin{array}{l}\text { Police assistance booths } \\
\text { (GRP) }\end{array}$ & 4.47 & 3.13 & 0.867500 & 0.5325 \\
\hline 19 & $\begin{array}{l}\text { Accessibility of station on } \\
\text { foot }\end{array}$ & 3.92 & 3.23 & 0.730000 & 0.5575 \\
\hline
\end{tabular}




\begin{tabular}{|c|l|c|c|c|c|}
\hline \multicolumn{1}{|c|}{ Amenities } & $\begin{array}{c}\text { Mean } \\
\text { (Importance } \\
\text { Level) }\end{array}$ & $\begin{array}{c}\text { Mean } \\
\text { (Satisfaction } \\
\text { Level) }\end{array}$ & $\begin{array}{c}\text { Importance } \\
\text { Index ( } \hat{I}_{E} \text { ) }\end{array}$ & $\begin{array}{c}\text { Satisfaction } \\
\left.\text { Index ( } \hat{I}_{S}\right)\end{array}$ \\
\hline 20 & $\begin{array}{l}\text { Accessibility of other modes } \\
\text { of transportation }\end{array}$ & 4.08 & 3.29 & 0.770000 & 0.5725 \\
\hline 21 & Four-wheeler parking space & 3.76 & 3.21 & 0.690000 & 0.5525 \\
\hline 22 & Two-wheeler parking space & 3.89 & 3.31 & 0.722500 & 0.5775 \\
\hline 23 & $\begin{array}{l}\text { Availability of foot-over } \\
\text { bridges }\end{array}$ & 4.11 & 3.53 & 0.777500 & 0.6325 \\
\hline 24 & Availability of escalators & 4.03 & 2.34 & 0.757500 & 0.3350 \\
\hline 25 & $\begin{array}{l}\text { Waiting time at enquiry } \\
\text { counter }\end{array}$ & 4.19 & 2.81 & 0.797500 & 0.4525 \\
\hline 26 & $\begin{array}{l}\text { Waiting time for travel- } \\
\text { related information }\end{array}$ & 3.95 & 2.94 & 0.737500 & 0.4850 \\
\hline 27 & Clarity of announcement & 4.45 & 3.31 & 0.862500 & 0.5775 \\
\hline 28 & Accuracy of announcement & 4.45 & 3.31 & 0.862500 & 0.5775 \\
\hline 29 & Cloak room & 3.79 & 2.97 & 0.697500 & 0.4925 \\
\hline 30 & ATMs & 4.31 & 2.84 & 0.827500 & 0.4600 \\
\hline 31 & Mobile charging points & 4.16 & 2.84 & 0.790000 & 0.4600 \\
\hline 32 & Internet facilities & 3.77 & 2.45 & 0.692500 & 0.3625 \\
\hline
\end{tabular}

FIGURE 2.

Service quality performance matrix calculations

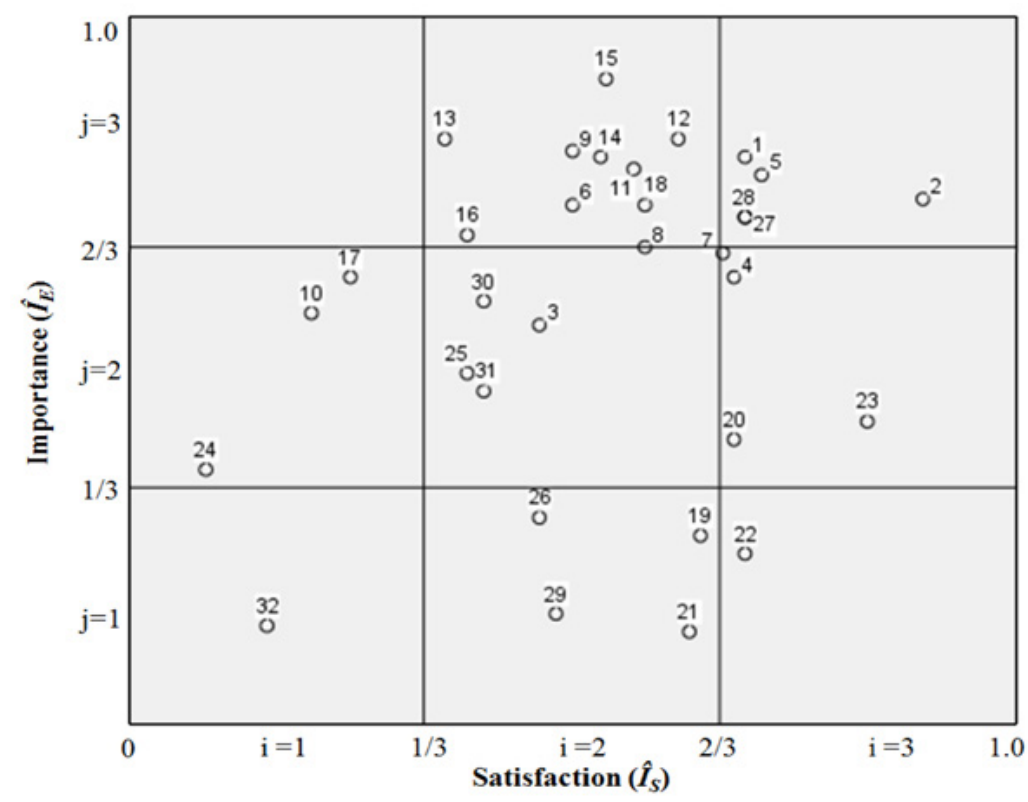

It is evident from Figure 2 that of the 32 amenities, 14 fall in the Definitely Improve and Improve regions, 10 in Maintain, and 8 in Reduce. Analyzing the nine zones, it can be concluded that none of the amenities falls in the LS-HI zone (Definitely Improve), and only one (internet facility) is in the LS-LI zone. The HS-LI zone also has only one amenity (two-wheeler parking space), and five amenities (waiting room, lighting at platforms, drinking water, clarity of announcement, and accuracy of announcement) are located in HS-HI zone. Of these, only lighting at platforms is at the extreme corner; the 
remainder are near the borderline. Thus, it is concluded that passenger satisfaction is moderate for the majority of amenities.

Maximum amenities (refreshment quality, refreshment affordability, washroom facility, cleanliness at platforms, cleanliness near waiting room, cleanliness near seating chairs, cleanliness in washrooms, cleanliness near refreshment stalls, cleanliness near water points, security for self, and police assistance booths) are located in the MS-HI zone, indicating that passengers are moderately satisfied with most of the amenities that are important to them. Zone LS-MI has only three amenities (cleanliness on tracks, security of luggage, and availability of escalators) that are moderately important for passengers, and their satisfaction level is on the lower side. For the four amenities located in the MS-MI zone (fans in platforms, waiting time at enquiry counters, ATMs, and mobile charging points), the satisfaction level is on par with the level of importance. Platform display, accessibility of other modes of transportation, and availability of foot-over bridges are in the HS-MI zone, and accessibility of station on foot, four-wheeler parking space, waiting time for travel-related information, and cloak room are in the MS-LI zone, which shows that, in all, there are seven amenities with which the satisfaction level of passengers exceeds their importance level. Two amenities, refreshment affordability and washroom facility, are on the border of the MS-MI and HS-MI zones and the MS$\mathrm{HI}$ and MS-MI zones, respectively, which implies that a concentrated effort could check the location of these amenities in the lower zone.

\section{Customer Satisfaction Index (CSI)}

Priority-wise, items for improvement per the CSI (see Table 4) are availability of escalators, cleanliness on tracks, security of luggage, security of self, cleanliness in washrooms, refreshment quality, cleanliness at platforms, washroom facility, cleanliness near refreshment stalls, police assistance booths, cleanliness near waiting room, cleanliness near water points, refreshment affordability, and cleanliness near seating chairs.

TABLE 4.

Priority List of Items for Improvement

\begin{tabular}{|c|l|c|}
\hline & \multicolumn{1}{|c|}{ Amenities } & Customer Satisfaction Index \\
\hline 1 & Availability of escalators & 9.43 \\
\hline 2 & Cleanliness on tracks & 10.85 \\
\hline 3 & Security of luggage & 11.31 \\
\hline 4 & Security of self & 12.42 \\
\hline 5 & Cleanliness in washrooms & 12.68 \\
\hline 6 & Refreshment quality & 13.41 \\
\hline 7 & Cleanliness at platforms & 13.68 \\
\hline 8 & Washroom facility & 13.77 \\
\hline 9 & Cleanliness near refreshment stalls & 13.87 \\
\hline 10 & Police assistance booths & 13.99 \\
\hline 11 & Cleanliness near waiting room & 14.09 \\
\hline 12 & Cleanliness near water points & 14.32 \\
\hline 13 & Refreshment affordability & 14.36 \\
\hline 14 & Cleanliness near seating chairs & 14.61 \\
\hline
\end{tabular}




\section{Conclusions and Recommendations}

\section{Conclusions}

This paper has identified amenities available at railway platforms that are significant for passenger satisfaction and has indicated amenities that need improvement and that need to be maintained. Improvement is required related to cleanliness (at platforms and washrooms; near waiting rooms, seating chairs, refreshment stalls, and water points; and on tracks), security of self and luggage, police assistance booths, refreshment quality and affordability, and availability of escalators. Ten amenities emerged that need to be maintained at their current levels. It can be concluded that aspects related to cleanliness and security are areas of concern, as all amenities under these two heads lie in the Improvement region. Of the 14 amenities that need to be improved on a priority basis, 10 are in the categories of cleanliness and security. Further, of top five items in the improvement priority list, two each are from the broad categories of cleanliness and security.

A train journey is more than the time spent inside the train; hence, railway operators must provide state-of-the-art services to customers even before they buy a ticket and until they reach their final destination (Pettersson 2011). Results presented herein give a clear picture with respect to Allahabad Junction and highlight the prioritization of improvements needed there to ensure a higher level of passenger satisfaction. These findings corroborate with the concerns of railway authorities regarding cleanliness, linking "Swachh Rail" with the "Swachh Bharat" drive.

\section{Recommendations}

To promote the ongoing nationwide cleanliness drive, Indian Railways announced a new department for cleanliness in its Railway Budget 2015-16. Therefore, efforts must be intensified to accomplish the mission of Swachh Rail-Swachh Bharat. Further, amenities such as accessibility of stations on foot, four-wheeler parking space, two-wheeler parking space, waiting time for travel-related information, and cloak rooms were found to have moderate to high levels of satisfaction in this study, but their importance is rated low. Therefore, it is recommended that the Ministry of Railways curtail funds from these amenities and divert them to other amenities that are high on the importance scale but have a low satisfaction level. For the remaining amenities, the Ministry of Railways should maintain the current status of service delivery because the satisfaction level of passengers equals their corresponding importance level.

The next aspect that needs immediate attention on the part of Ministry of Railways is security mechanism at platforms. Provision of safety measures such as body and luggage scanners, metal detectors, CCTV cameras (equipped with facial recognition technology), and fire detection and suppression systems, as proposed by the Ministry (Railway Board 2009) at every railway station, is expected to enhance the safety and security of passengers at platforms. According to Crime Concern (2002), researchers in the United Kingdom concluded that a sense of safety and security among passengers in trains and at stations is likely to result in an additional $10.5 \%$ in train trips (Currie, Delbosc, and Mahmoud 2013). Studies have established that people usually feel unsafe in public transportation areas; this underlines the significance of lighting in the context 
of safety at railway platforms (Vos 2013). Johansson, Rosein, and Kuler (2011) suggest that bright, evenly-distributed, and monotone lights produce the highest feelings of safety. Thus, lighting at platforms as an amenity under Factor 1 (Passenger Amenities) can be linked with Factor 3 (Safety \& Security). Enhancement of social safety also can be an outcome of establishing a clean environment at railway platforms (Vos 2013).

Providing good quality food at platforms is of immense importance. Findings showed that the quality and affordability of refreshments at Allahabad Junction are in Improvement zone (MS-HI) in the service quality performance matrix, thus causing dissatisfaction. Refreshments aid in the mitigation of the discomfort of passengers waiting at platforms (Geetika and Nandan 2010). Indian Railways should offer refreshment stalls and conduct surprise visits and inspections for continuous evaluation of service performance, including quality and price of refreshments offered by vendors.

\section{Limitations of the Study and Scope for Further Research}

This paper is based on a survey conducted at one railway station, and findings could differ if more stations are included. The perceptions of passengers, condition of platforms, levels of satisfaction, etc., could vary depending upon the level of development of the respective state/city. This study has not considered the opinions of respondent-passengers on satisfaction/dissatisfaction. Further research on assessment of specific reasons for dissatisfaction of passengers with selected amenities is welcomed.

\section{References}

Abu-ELSamen, A., M. N. F. Akroush, A. L. Al-Sayed, and H. J. Hasan, H. J. 2012. "An Empirical Model of Customer Service Quality and Customer Loyalty in an International Electronics Company." International Journal of Electronic Business, 10(1): 39-63.

Agarwal, R. 2008. "Public Transportation and Customer Satisfaction: The Case of Indian Railways." Global Business Review, 9(2): 257-72.

Atkins, S. T. 1990. "Personal Security as a Transport Issue, a State of the Art Review." Transportation Reviews, 10(2): 111-125.

Campell, D. T., and D. W. Fiske. 1959. "Convergent and Discriminant Validation by the Multi Trait-Multi Method Matrix." Psychological Bulletin, 56(2): 81-105.

Cavana, R. Y., L. M. Corbett, and Y. L. Lo. 2007. “Developing Zones of Tolerance for Managing Passenger Rail Service Quality." International Journal of Quality \& Reliability Management, 24(1): 7-31.

Chen, C. F. 2008. "Investigating Structural Relationships between Service Quality, Perceived Value, Satisfaction, and Behavioral Intentions for Air Passengers: Evidence from Taiwan." Transportation Research Part A, 42(4): 709-717

Chen, S. H., C. C. Yang, W. T. Lin, and T. M. Yeh. 2007. "Service Quality Attributes Determine Improvement Priority." The TQM Magazine, 19(2): 162-175. 
Choi, K. S., W. H. Cho, S. Lee, H. Lee, and C. Kim. 2004. “The Relationships among Quality, Value, Satisfaction and Behavioral Intention in Health Care Provider Choice: A South Korean Study." Journal of Business Research, 57(8): 913-921.

Crime Concern. 2002. "People Perceptions of Personal Security and Their Concerns about Crime on Public Transport: Literature Review." London, UK: Department for Transport.

Currie, G., A. Delbosc, and S. Mahmoud. 2013. "Factors Influencing Young Peoples' Perceptions of Personal Safety on Public Transport." Journal of Public Transportation, 16(1): 1-19.

Dash, S., S. R. Dash, and S. K. Pradhan. 2012. "Measuring Service Quality of Railway Platforms in India: A Case-Study of East-Coast Railways." International Journal of Research in Computer Application \& Management, 2(12): 129-134.

Drea, J. T., and J. B. Hanna. 2000. "Niche Marketing in Intrastate Passenger Rail Transportation." Transportation Journal: 33-43.

Esmaeili, A. A., B. A. Manesh, and E. Golshan. 2013. "Service Quality, Customer Satisfaction and Customer Loyalty in RAJA Rail Transportation Company." International Research Journal of Applied and Basic Sciences, 4(12): 4248-4253.

Field, A. 2009. Discovering Statistics using SPSS. London: Sage Publications Ltd.

Gallup Organization. 2011. Survey on Passengers' Satisfaction with Rail Services. Hungary: European Commission.

Gandhimathi, S., and S. Saravanan. 2013. "A Study on Passenger's Satisfaction towards Railway Services in Coimbatore Junction." International Journal of Applied Research and Studies, 2(11): 1-6.

Geetika and S. Nandan. 2010. "Determinants of Customer Satisfaction on Service Quality: A Study of Railway Platforms in India." Journal of Public Transportation, 13(1): 97-113.

Giannoccaro, R., N. Costantino, A. D. Ludovico, and R. Pietroforte. 2008. “Measuring Citizen Satisfaction with Aspects of Public Services from a Local Authority and Determining Their importance: A Case Study." Public Organization Review, 8(1): 1-15.

Givoni, M., and P. Rietveld. 2007. "The Access Journey to the Railway Station and Its Role in Passengers' Satisfaction with Rail Travel." Transport Policy, 14: 357-365.

Grönroos, C. 1988. "Service Quality: The Six Criteria of Good Service Quality." In Review of Business. New York: St. John's University Press.

Guirao, B., A. Garcia, M. E. López, and C. Acha. 2015. “New QR Survey Methodologies to Analyze User Perception of Service Quality in Public Transport: The Experience of Madrid." Journal of Public Transportation, 18(3): 71-81.

Gupta, S., and R. Datta. 2012. "Prioritizing Service Attributes for Quality Up Gradation of Indian Railway Stations." The TQM Journal, 24(2): 167-180. 
Hall, A. L., and R. C. Rist. 1999. "Integrating Multiple Qualitative Research Methods." Psychology and Marketing, 16(4): 291-304.

Hanumappa, D., P. Ramachandran, T. G. Sitharam, and S. Lakshmana. 2015. "Performance Evaluation of Bangalore Metropolitan Transport Corporation: An Application of Data Envelopment Analysis." Journal of Public Transportation, 18(2): 1-19.

Hung, Y. H., M. L. Huang, and K. S. Chen. 2003. "Service Quality Evaluation by Service Quality Performance Matrix." Total Quality Management and Business Excellence, 14(1): 79-89.

Johansson, M., M. Rosén, and R. Küller. 2011. "Individual Factors Influencing the Assessment of the Outdoor Lighting of an Urban Footpath." Lighting Research and Technology, 43: 31-43.

Juran, G. 1998. Juran's Quality Handbook (5th ed.). New York, NY: McGraw-Hill.

Lambert, D. M., and A. Sharma. 1990. "A Customer-Based Competitive Analysis for Logistics Decisions." International Journal of Physical Distribution \& Logistics Management, 20(1): 17-24.

Lai, W. T., and C. F. Chen. 2011. "Behavioral Intentions of Public Transit Passengers-The Roles of Service Quality, Perceived Value, Satisfaction and Involvement." Transport Policy, 18(2): 318-325.

Le-Klähn, D. T., C. M. Hall, and R. Gerike. 2014. "Analysis of Visitor Satisfaction with Public Transport in Munich. Journal of Public Transportation, 17(3): 68-85.

Pettersson, P. 2011. “Passenger Waiting Strategies on Railway Platforms - Effects of Information and Platform Facilities: Case Study Sweden and Japan." Master of Science Thesis, Stockholm.

Pratminingsih, S. A., C. L. Rudatin, and A. R. Suhardi. 2014. "Retaining Passengers Loyalty in Indonesia Railway Service." Journal of Global Management, 7(1): 60-75.

Railway Board. 2009. "Indian Railways." White paper for Railway Board Publication.

Railway Board. 2015. “Indian Railway Budget Speech 2015-16." Retrieved March 2015 from http://www.indianrailways.gov.in/railwayboard/uploads/directorate/finance _ budget/Budget_2015-16/Railway_Budget_Speech_2015-16\%20(English).pdf.

Rajeswari, V., and K. S. Kumari, K. S. 2014. "Satisfaction and Service Quality in Indian Railways-A Study on Passenger Perspective." IOSR Journal of Economics and Finance, 4(1): 58-66.

Sharma, A. K. 2009. "Modernization of Railway Stations in India: A Case for PublicPrivate Partnership with Special Reference to New Delhi Railway Station." South Asian Journal of Management, 16(1): 102-116.

Sheeba, A. A., and K. Kumuthadevi. 2013. "Service Quality of South Indian RailwayDeterminants of Passenger Satisfaction in Trains." International Journal of Business and Management Invention, 2(2): 49-54. 
Swami, M., and M. Parida. 2015." Comparative Appraisal of Metro Stations in Delhi using Data Envelopment Analysis in a Multimodal Context." Journal of Public Transportation, 18(3): 29-51.

Van Hagen, M., A. Pruyn, M. Galetzka, and J. Sauren. 2010. "Music at Railway Stations: The Influence of Music on Waiting Experience." Presentation at European Transport Conference, 2010.

Van't Hof, K. 2008. "Circling Safety. Feeling (un)Safe at Railway Stations." Master's thesis, University of Twente, Enschede.

Vos, L. 2013. "The Effects of Lighting and Disorder on the Perception of Social Safety of Waiting Passengers at a Railway Station Platform." Master's thesis, University of Twente, Enschede.

Yang, C. C. 2003. "Improvement Actions Based on the Customers' Satisfaction Survey." Total Quality Management and Business Excellence, 14(8): 919-930.

Zeithaml, V. A., and M. J. Bitner. 1996. Services Marketing. New York, NY: McGraw-Hill.

\section{About the Authors}

GeETIKA (geetika@mnnit.ac.in) is a Professor in the School of Management and Dean of Academic Affairs at Motilal Nehru National Institute of Technology, Allahabad, and an Adjunct Professor at the Asian Institute of Technology in Thailand. Her research interests lie in the areas of strategic management and entrepreneurship. She has co-authored 5 books and more than 60 research papers published in national and international journals and has guided more than 10 doctoral students.

PiYal Ghosh (piyali2602@gmail.com) is an Assistant Professor with the School of Management Studies at Motilal Nehru National Institute of Technology in Allahabad. Her research interests lie in industrial relations and training \& development. She has co-authored books on managerial economics and industrial relations \& labor law for McGraw Hill Education and has published more than 25 research papers in national and international journals.

Mohit KUMAR OJHA (mohitojha.kr@gmail.com) is a Research Scholar in the School of Management Studies at Motilal Nehru National Institute of Technology in Allahabad. He is working in the area of railway station modernization through public-private partnerships as his doctoral research. His areas of specialization include finance and marketing, and his research interest lies in strategic management.

SUMIT KUMAR (sumit.mnitian@gmail.com) is an MBA student in the School of Management Studies at Motilal Nehru National Institute of Technology. His areas of specialization include finance and marketing. 